IНТЕРМАРУМ: історія, політика, культура. - Вип. 8.

UDC 94 (477.8)"1918/1939"

DOI 10.35433/history.11202

Matviichuk Vitalii,

Postgraduate Student at the Department of History of Ukraine, Zhytomyr Ivan Franko State University matviychuk_witaliy@ukr.net

\title{
RESTORATION OF STATEHOOD \\ IN THE POLITICS OF MEMORY OF THE SECOND POLISH- LITHUANIAN COMMONWEALTH (THE CASE OF WESTERN UKRAINE)
}

\section{Abstract}

The aim of the article is to study the politics of memory of the Second Polish-Lithuanian Commonwealth in the 1920s-1930s in Western Ukraine associated with the restoration of the Polish statehood. The methodology of scientific research is based on general scientific and special historical methods, including the basic principles of historical perception. The principles of historicism and scientific character of research enabled the author to recreate the politics of memory of the Second Polish-Lithuanian Commonwealth in Western Ukraine in all its complexity and diversity, as well as in interrelation and interdependence with the events of that time. The principle of objectivity facilitated the consideration of the outlined problems taking into account objective historical patterns and a critical analysis of the reference database. The principle of consistency provided the means to form a complete account of the corresponding commemorative practices. The scientific novelty of the research lies in the fact that for the first time the problem of reflecting the historical subject of the restoration of Poland in the political power of memory in Western Ukraine is studied on the basis of a big archive database. As a result, the author comes to the conclusion that the "memory" of the state restoration was actively implemented throughout its territory, including Western Ukraine. Due to the corresponding politics of memory, the Polish authorities tried to integrate Western Ukraine into a single social and cultural space, the creation of which was quite a difficult task for the postwar Poland. Historical subjects and various kinds of commemorations became unified on the entire territory of the state. Some of the local subjects, for example, "Lviv Eaglets" or the battles of legionnaires near Kostiukhnivka became national, and strengthened the position of the Polish state narrative in Western 
INTERMARUM: history, policy, culture. - Issue 8.

Ukrainian region. The author argues that the activity of memorialization in Western Ukrainian cities led to the filling of the memory space with Polish symbols. The paper considers the issue of formalism and monotony of Polish commemorative practices in Western Ukraine.

Key words: commemorative practices, politics of memory, Western Ukraine, postwar period, Second Polish-Lithuanian Commonwealth.

Introduction. The consequence of World War I and the Treaty of Versailles was the formation of a number of new states that appeared in a kind of political vacuum in Central and Eastern Europe. The countries that emerged in these territories were multiethnic, but only one community usually formed the national political project. Even such states as Czechoslovakia or Yugoslavia were no exception to this rule, because the Czechs played the dominant role in the first country, and the Serbs - in the second. Very often, these states needed an ideology that could unite their different ethnic content. An important role in this context was played by politics of memory, which became an instrument of political control in the newly emerged states. The multiethnic Second Polish-Lithuanian Commonwealth is a vivid example of such a state. In the processes of forming its politics of memory, they used the subject that was meaningful to that very society, at that very time, namely, the fight for the restoration of the state between 1914-1920.

Primarily the foreign historians studied the problem of the restoration of the Second Polish-Lithuanian Commonwealth in the Polish politics of memory of the postwar period in Western Ukraine. Among them, the Polish and American researcher M. Biskupski (Biskupski, 2012, pp. 51-52) is worth mentioning. He provided a thorough analysis of the evolution of the state holiday on November 11 and its role in the history of Poland. The findings of the Polish researcher J. Załęczny are also crucial for our research (Załęczny, 2017, 444 p.). In her works, the author raised an important issue of the formation of the cult of J. Pilsudski in the Polish postwar society (Załęczny, Kult Piłsudskiego przed i po maju, 2016), as well as the problem of commemorative practices and their evolution in the Second Polish-Lithuanian Commonwealth (Załęczny, Tradycje patriotyczne elementem kształtowania zbiorowej świadomości historycznej w II rzeczypospolitej, 2017). However, for the most part, the researcher 
IНТЕРМАРУМ: історія, політика, культура. - Вип. 8.

focuses on the ethnic Polish territories. We learn about the commemorative practices carried out by the Polish authorities in Western Ukraine from the works of R. Holyk (Holyk, 2009, pp. 62-75), C. Mick (Mick, 2016, pp. 233-257), O. Vynnyk (Vynnyk, 2018, 238 p.) and others. In general, this research topic has not yet become a separate object of a historic study.

In the proposed study, we use the definition of "politics of memory" as defined by a Ukrainian historian H. Kasianov. "It is a kind of politics, the aim and content of which is the purposeful construction and utilitarian use of historical memory and other forms of collective ideas about the past and past representations, including professional historiography, for political purposes" (Kasianov, 2016, pp. 118-137).

The aim of this paper is to highlight the main events related to the narrative of restoration of Poland in the period of 1914-1920, and carried out by the Polish authorities in Western Ukraine as part of politics of memory implementation.

The outline of the material. Having restored the Polish state in 1918 , the ruling elites faced the problem of integration. There were five monetary units in circulation; five major regions that became parts of the state (Silesia, Poznan region, Cieszyn, Vilno and Eastern Galicia) had different administrative systems; orders in the army were given in four languages; there were three criminal codes; and railways had two different track widths (Davies, 2008, p. 746). The situation was complicated by the fact that in the newly created Second PolishLithuanian Commonwealth there was no single Polish nation, and about $80 \%$ of its Polish-speaking residents did not identify themselves with the Polish national project. This statistic is confirmed by a catastrophic situation that arose due to the Bolshevik threat in the summer of 1920 , when the Polish army suffered from an acute shortage of recruits and volunteers. Polish historians emphasize on a complete lack of patriotism outside big cities. The peasants had to be intimidated to send their sons to the army and to give their food and property for the needs of the military machine. When the volunteer army began to be formed under the leadership of General Y. Haller, only one in five soldiers came from a village, although in 1920, four fifths of the Polish people lived in the countryside (Böhler, 2018, pp. 21-186). 
INTERMARUM: history, policy, culture. - Issue 8.

The residents of the so-called Eastern Kresy, populated mainly by the Ukrainians and Belarusians opposed to the Polish national project even more. A striking example of this conflict is the state of legionnaires' burials in the village of Kostiukhnivka (now Volyn region, Ukraine), which by the mid-1920s became a site of cult for the Polish patriots. However, by that time the local peasantry had destroyed the tombs, demolished the crosses on the graves because they interfered with their work in the fields (Kaczyński, 2016, pp. 135-151).

Furthermore, the majority of the region's population in the first years of Poland's restoration neither supported nor understood their own national state projects. For instance, it was due to the inactiveness of the Ukrainian village that the guerrilla warfare waged by the members of the Ukrainian Military Organization, former soldiers of the Galician army, and the UPR army in the 1920s was brought to naught (Fedevych, 2009, p. 222).

According to the Belarusian researcher A. Krutikov, the Polish national idea at that time was characterized by its fragmentation, lack of a clear cultural connection between individual regions, as well as by the multinational nature of the state. This made the Second PolishLithuanian Commonwealth similar to the Austro-Hungarian Empire (Krutikov, 2019). Therefore, the formation of politics of memory and making it the tool to restore the state became the priority tasks of Polish governments of the postwar period. The creation of common historical myths, symbols, and stereotypes should have encouraged the integration of the Second Polish-Lithuanian Commonwealth society. However, this did not happen, because politics of memory reconstructed the Polish political nation in the first instance. According to the German historian J. Böhler, "ethnically, the state represented primarily the Polish majority, but was drawn into a deep internal struggle willing to reconcile with large minorities of the Ukrainians, Jews and Germans, who did not weaken but gained strength in the 1930s" (Böhler, 2018, p. 48).

The date of November 11 is an integral part in the policy of commemoration of the Second Polish-Lithuanian Commonwealth. The first solemn events took place in 1919 (Krutikov, 2019), but as a holiday this day began to be celebrated in 1920, although it was still unofficial and was limited to military ceremonies and solemn church services 
IНТЕРМАРУМ: історія, політика, культура. - Вип. 8.

(Załęczny, Tradycje patriotyczne elementem kształtowania zbiorowej świadomości historycznej W II rzeczypospolitej, 2017, p. 186). At the local level in Lviv, the solemn events coincided with the second anniversary of the victory of Polish military detachments over the Galician army of the West Ukrainian People's Republic. On this occasion, the city hosted a week of festivities, which began on November 14 with a literary evening dedicated to "Eagles" (Wieczor Orlat), where literary works were performed in the memory of the Polish defenders of Lviv (W drugę rocznicę oswobodzenia Lwowa, 1920 , n. 260, p. 3). The week ended on Sunday, November 21, with a solemn service at the burial site of the first Polish defenders of the city (W drugę rocznicę oswobodzenia Lwowa, 1920, n. 264 p. 3). However, a wide range of celebrations took place the next day with the arrival of J. Pilsudski, who awarded Lviv with the Order of "Virtuti Militari" (W dzień chwały, 1920, pp. 1-3). It was Lviv that became the first city in the Second Polish-Lithuanian Commonwealth to receive the award of this level. The celebrations were accompanied with the military parade, a solemn mass and a leader's visit to the graves of Polish defenders at the Lychakiv cemetery (Kronika polityczna, 1920, p. 4). Over the time, this combination of local and national commemorations will become traditional for Lviv.

The institutionalization of November 11 as Independence Day (Dzień Niepodlegtości) intensified after the May upheaval of 1926 (the official approval of Independence Day took place only in 1937). According to researcher M. Biskupski, celebrations of national holidays were a conscious step in creating public support for J. Pilsudski and his regime at the time.

J. Pilsudski and his associates sought to form civil patriotism based on tolerance towards minorities (however, such ideas were at odds with real practice). This patriotism lacked new symbols. Therefore, starting from 1926, schools and government offices didn't work on Independence Day, and city authorities issued memoranda in which November 10-11 was considered a holiday. At the same time, since 1918, Lviv was set against Warsaw and due to political events Warsaw - Lviv relations turned into relationships between Pilsudski - "endeki (National democrats)". Therefore, the Lviv authorities interpreted the scale of the upcoming ceremonies in their own way: they considered it 
INTERMARUM: history, policy, culture. - Issue 8.

to be a good warning for the Ukrainians about the strength of the Polish presence in the region (Biskupski, 2012, pp. 51-52). The situation was different in the provinces. The aim of November 11 celebration was to unite Polish citizens of different ethnic backgrounds around the same symbols and myths. This policy, in particular, can be traced in Volyn region. Thus, the main message of the celebration of Independence Day in Sarny was the old motto of the Polish Socialist Party - "free person is with the free, an equal person is with the equal" (Biskupski, 2012, p. 61).

The military men were actively involved in the celebrations. On the 10th anniversary of the Independence, Southeastern Union of reserve officers (Związek Oficerów Rezerwy Ziem Poludniowo-Wschodnich) undertook a running race to the capital to pass a symbolic tribute of Chervenska land to J. Pilsudski (Załęczny, Tradycje patriotyczne elementem kształtowania zbiorowej świadomości historycznej W II Rzeczypospolitej, 2017, p. 189). The active participation of the military in the Independence Day celebration is the evidence of strength and invincibility cult formation, which was also reflected in the construction of the image of Polish legions as an integral part of a new national myth.

The memorial site in the mentioned above village of Kostiukhnivka occupied an important place of memory in the formation of a new policy in Volyn region. During World War I in the summer of 1916, there are intense battles of Polish legionnaires and as a result about two thousand soldiers were killed, wounded and went missing (Waingertner, 2017, pp. 39-51). After Poland gained its Independence, the battlefield near Kostiukhnivka turned into a memorial site. Basalt obelisks, pillars of memory, were installed in the selected places. By the fall of 1938, there were nine of them. In 1933, they laid a foundation of a burial mound in honor of the legionnaires (Kopiec Chwaty Legoinów). It was planned that it would be 25 meters high and 75 meters wide, and there would be a museum at its feet. The construction was expected to have been completed by 1942 . In addition, a specially created committee that dealt with burials in Kostiukhnivka (Komitet Opieki nad Pobojowiskami Legionów Polskich) began working on the construction of a historical and tourist route to places of military engagement. For this reason, trenches and fortifications were intentionally restored and reconstructed. On the 20th anniversary of the battle in 1936 the memorial site was 
IНТЕРМАРУМ: історія, політика, культура. - Вип. 8.

partly adapted for educational and tourist purposes. (Kaczyński, 2016, pp. 135-151).

A particular commemorative practice of the postwar period was the cult of the "Unknown Soldier". First, it became widespread in Britain and France (November 1920), and the following year - in Italy, the United States, and Portugal. Poland borrowed this cult in 1925 (Vynnyk, 2018, pp. 303-304). The Unknown Soldier represented the memory of those who died not only in World War I, but also in previous and subsequent wars (Mick, The Dead and Alive: War Veterans and Memorial Culture in Interwar Polish Galicia, 2016, pp. 233-257).

In May 1925, premises of the Polish military council hosted the ceremony, where the youngest holder of the order "Virtuti Militari" randomly pulled out a piece of paper with the name of "Battle for Lviv" (Bojowisko Lwowskie) from the urn containing the names of 15 battlefields. This meant that the Polish Unknown Soldier would be a person who participated in the Polish-Ukrainian war of 1918-1919 (Mick, Lemberg, Lwów, L'viv, 1914-1947: Violence and Ethnicity in a Contested City, 2016, p. 236). According to the Ukrainian historian S. Lypovetskiy, not everybody from the Polish community welcomed this choice. In the article, the author quotes the words of Ya. Los, a representative of the Polish-Ukrainian misunderstanding. He said that "the subconscious tendency of the Poles to consider the Polish-Russian struggle in 1918 and 1919 to be some kind of external war was very characteristically manifested in one significant detail: it was from Lviv battlefield that the body of the Unknown Soldier was transported to Warsaw. It is incompatible with the truth, it is undoubtedly harmful for the Poles, but even more so for the Ukrainians" (Lypovetskiy, 2019).

Nevertheless, solemn reburial events still took place. The exhumation and transportation of the Unknown Soldier continued throughout October 29-31, 1925, and immediately turned into a complex political ritual. The coffin was moved from the cemetery of "Lviv Defenders" to the cathedral, and from there to the railway station. The Guard of Honor symbolically consisted of two Polish disabled veterans, two mothers who lost their sons, two widows and two orphans (Vynnyk, 2018, p. 304). The train was accompanied by railway workers with torches in their hands throughout the city of Lviv. On its way to Warsaw it made several stops. The first station after Lviv was Zhovkva, 
INTERMARUM: history, policy, culture. - Issue 8.

where the local peasantry and schoolchildren greeted Unknown Soldier and the station itself was decorated with Polish national flags. A military orchestra was playing at the Rava-Ruska station. Similar events were held at other train stops (Wzdłuż ostatniej drogi Nieznanego Żołnierza, 1925, p. 2).

According to G. Rossolinskyi-Liebe after World War I the romantic-national component of Polish nationalism was replaced by the glorification of the struggle for Lviv and Eastern Galicia. Therefore, soldiers immortalized in stone or bronze, became new emblematic objects (Liebe, 2009, p. 10). In 1928 (according to other sources, in 1926 (the wheel of history)) in Lutsk, near the cathedral, a tombstone monument was erected (Lys, 2012) with the words "to those who fell for Lutsk freedom... at the hands of Red ferocity" (the wheel of history). On the 15th anniversary of Independence day in Drohobych, a memorial board dedicated to 14 young people who "followed Jozef Pilsudski's appeal to fight for the freedom and independence of the Motherland in 1914-1920 and sacrificed their young lives" was set up at a secondary school (Załęczny, Pamięć o uczestnikach wojny 1920 roku w świadomości społeczeństwa II Rp, 2019, pp. 185-209).

The most important place of worship for the Poles in Western Ukraine, which gave a rise to a separate legend, was the "Memorial to Lviv Eaglets". The Polish society for the protection of War Graves (Straz Mogit Polskich Bohaterów) worked on the creation of the memorial site in 1919, and the city authorities provided the financial support. The main works were completed by the mid-1930s (Charczuk, 2014, pp. 50-54). The memorialization of the" eaglets" contributed to the aggravation of the conflict between the Ukrainians and the Poles:

"There are a lot of names, different military ranks, they were with different weapons, and who will count the battlefields where they lie? The blood of some flowed down the paving stones of Lviv, others died heroically on other fields of "blood and glory", either absorbing blood on their heartfelt way to Lviv with the "Ukrainian" owners, or a year later, resisting the Bolsheviks' invasion with small forces". This is how the author of a tourist guide to the sights of the city describes Polish burials (Medyński, 1937, p. 201).

The symbolism of Lviv Eaglets, which was compared to the "children's crusade", shifted to a school history context. The pages of 
IНТЕРМАРУМ: історія, політика, культура. - Вип. 8.

school textbooks depicted an unequal battle between the Poles and twenty thousand Ukrainian soldiers. In his article, a well-known Ukrainian historian R. Holyk gives an example of how Lviv battles were depicted for the 4th graders: "older children, secondary school students with battle rifles in their hands guarded the territory and participated in battles. Girls helped in hospitals, brought food to the warring soldiers, and took the wounded. Older girls and adult women stood next to the fighting men and bravely went into the assault" (Holyk, 2009, p. 67-68). An American historian A. Megill calls this approach of highlighting the past an affirmative one. The affirmative historiography is designed to subordinate the past to the projects that society is engaged in nowadays. It lacks a critical attitude towards memories, as well as to the traditions it supports. Such historiography tends towards mythologization (Megill, 2007, p. 99).

J. Pilsudski was the central figure of the Polish cult of the state restoration in 1918. The cult of the leader of the Polish people grew out of the "Legionnaire Legend" of World War I. It was then that for the first time the birthday of J. Pilsudski (March 19) started to be celebrated in the circle of legionnaires. Later, this date was included into the political calendar of the Second Polish-Lithuanian Commonwealth (Załęczny, Kult Piłsudskiego przed i po maju, 2016, p. 60). The date was also actively celebrated in Western Ukraine. On March 19, 1922, in Ternopil, houses were decorated with banners and portraits of $\mathrm{J}$. Pilsudski, and a mass and a military parade were the central events, which unfolded in the city square. The same events were held in Lviv. Similar, but smaller celebrations took place on this day in Lutsk (Obchód imenin Naczelnika Państwa, 1922, p. 4).

In 1923, the Institute for the Study of Modern History under the leadership of L. Wasylevski was established in Poland. This university had an exclusive right to use archival materials and sources on the history about the struggle for Independence, they also initiated the creation of an official biography of J. Pilsudski. The Military Scientific and Publishing Institute performed similar functions, only in the army (Krutikov, 2019). Thus, even before the military upheaval, the cult of J. Pilsudski had been formed and actively spread throughout of the country. Since 1926, it became a state mythology (Krutikov, 2019). According to the Polish researcher J. Załęczny: "the cult of Pilsudski is 
INTERMARUM: history, policy, culture. - Issue 8.

not just about worshipping him because of his achievements. They used the character of the marshal to build the position of the sanation camps, and before that it was used to fill the gap in the national identity and integration of the young state" (Załęczny, Kult Piłsudskiego przed i po maju, 2016, p. 55).

The active promotion of J. Pilsudski's cult made the resistant part of the society oppose even more. Sometimes, especially during the crisis in 1920s-1930s, this movement would incite street demonstrations and organize alternative events (Cicharacki, 2010). This way the Ukrainian youth boycotted the celebration of J. Pilsudski's birthday in the Ternopil region quite powerfully (Sakivskii, 2017, p. 54).

Another problem, but just as important, was the formal character of the celebrations. The great example of that was the scandalous situation that happened in the Stanislavskyi Voivodeship. Leading Polish newspapers reported that the central authorities of the Voivodeship forced counties to adopt greeting resolutions in honor of J. Pilsudski's birthday. They received a corresponding decree from the Dolynskyi starosty to all the gminas of the county and immediately replicated it in their publications (Havrylyshyn, P., Chornenkyi, R. Pilsudski in Stanislawow and Voivodeship). Editors of "Robotnik" ("Robotnik: centralny organ P.P.S.") considered it morally unacceptable (Po imieninach marsz. Piłsudskiego, 1920, p. 2), and in the newspaper "Dziennik Ludowy" ("Dziennik Ludowy: organ Polskiej Partji Socjalistycznej"), the authors eloquently refused any commentaries (Czy marsz. Piłsudski wie o tem? 1929, p. 3). Subsequently, the Dolynskyi county chairman was forced to explain that he issued this decree because of the low intellectual abilities of gminas leaders:

"I know all the leaders of gminas under my control, who, with minimal exceptions, are peasants with a primary level of culture, they have no idea what the name of Mr. Marshal is and when his birthday is" (Havrylyshyn, P., Chornenkyi, R. Pilsudski in Stanislawow and Voivodeship).

One of the features of the cult was the establishment of lifelong monuments to the leader. The first of them was established even before the upheaval in 1925 (Załęczny, Kult Piłsudskiego przed i po maju, 2016, p. 67). One of the first lifetime monuments appeared in 1929 in Kolomyia in Western Ukraine. The rector of the Krakow Academy of 
IНТЕРМАРУМ: історія, політика, культура. - Вип. 8.

Arts K. Lezak made a bronze sculpture of the leader. The marshal was depicted with a Legionnaire's award on his uniform, holding a sword in his right hand, and a book with the inscription "Will, equality, brotherhood" in his left (Nahirnyi, 2010, pp. 199-201).

However, the largest monument to the leader of the interwar period appeared in Ternopyl. It was made in a natural size. On the main pedestal there was a symbolic inscription: "To the leader of the people. The Land of Podilsk", and on both sides there were sculptures of two Polish soldiers with the signatures "1914" and "1920" (Tarnopol na starych zdjęciach. Kresy Wschodnie przed II wojna światowa). Other cities of Western Ukraine also had monuments to the leader. They often became objects of vandalism by the dissatisfied Ukrainian nationalist youth. In 1933, the monument to J. Pilsudski was severely damaged. V. Rogovskyi, a member of the OUN underground was arrested on suspicion of committing this act (Sakivskii, 2017, p 117). The cult of the Initial Leader grew after his death in 1935, and existed up the beginning of World War II.

Taking everything mentioned above into consideration, we come up to the following conclusions. A new national myth about the Second Polish-Lithuanian Commonwealth needed to be spread and supported throughout the state. Western Ukraine, which the Polish authorities tried to integrate into their social and cultural space, was of no exception. The politics of memory was one of the tools of this integration. Some local myths that emerged in Western Ukraine, such as stories about "Lviv Eaglets" or the battles of legionnaires near Kostiukhnivka, became national. The celebration of November 11 was combined with the anniversaries of the battles for Lviv, which were celebrated by the Polish community of the city. The memorialization of Western Ukrainian cities was becoming active, which led to the filling of the symbolic space of memory with the Polish symbols. The installation of monuments to the Polish leader J. Pilsudski also became traditional. A particular feature of the commemorative practices carried out by the Poles during the postwar period was their formal character and monotony. In general, it can be assumed that the path chosen by the official Polish authorities did not contribute to the integration of Western Ukraine, but further deepened the existing gap between the minorities and the Polish majority. 
INTERMARUM: history, policy, culture. - Issue 8 .

It should be noted that the outlined problems have prospects for further investigations. The correlation of politics of memory with other areas of the Polish policy in the region has a significant potential for studying. A comparative analysis of the politics of memory of the Second Polish-Lithuanian Commonwealth in Western Ukraine with the politics of memory of other territories, including national parts of the Polish state, is also crucial.

Gratitude. I would like to thank the members of the journal's editorial board and reviewers for their constructive comments, suggestions and advice provided during the preparation of the article for publication.

Financing. The author did not receive financial support for the research and publication of this article.

\section{References}

Biskupski, M. (2012). Independence Day: Myth, Symbol, and the Creation of Modern Poland. Oxford: Oxford University Press. 200 p. [in English].

Böhler, J. (2018). Wojna domowa. Nowe spojrzenie na odrodzenie Polski. Kraków: Znak Horyzont. 336 s. [in Polish].

Charczuk, K. (2014). Działalność Polskiego towarzystwa opieki nad grobami bogaterów we Lwowie w okresie mięndzywojennym, Young Scientist, 8(11), ss. 50-54. [in Polish].

Cicharacki, P. (2010). Legenda Yuzefa Pilsudskogo v pol'skom obshchestve mezhvoiennogo perioda (1918-1939 годы) [Josef Pilsudski's Legend in the interwar Polish Society]. URL: https://cyberleninka.ru/article/n/legenda-yuzefa-pilsudskogo-v-polskomobschestve-mezhvoennogo-perioda-1918-1939-gody. [in Russian]. (Accessed 19 February 2020).

Czy marsz. Piłsudski wie o tem? (1929). Dziennik Ludowy: organ Polskiej Partji Socjalistycznej, 18 marca, s. 3. [in Polish].

Davies, N. (2008). God's Playground. A History of Poland. Kyiv: Osnovy. 1080 p. [in Ukrainian].

Fedevych, K. (2009). Halystki ukraintsi u Polschchi 1920-1939 rr. (Intehratsia halytskykh ukraintsiv do Pol'skoii derzhavy y 1920-1930-ti rr.) [Halytski Urkainians in Poland in 1920s-1930s (Halytski Urkainians Integration into the Polish State in 1920s-1930s. Kyiv: Osnovy. 280 p. [in Ukrainian]. 
IНТЕРМАРУМ: історія, політика, культура. - Вип. 8.

Havrylyshyn, P., Chornenkyi, R. Pilsudski in Stanislawow and voivodeship. URL: http://gk-press.if.ua/pilsudskyj-u-stanyslavovi-tavoyevodstvi/. [in Ukrainian]. (Accessed 19 February 2020).

Holyk, R. (2009). The West Ukrainian People's Republic or Malopolska Wshodnia?: the image of 1918 Galicia in the Ukrainian and Polish mentality. Ukraine: cultural heritage, national consciousness, statehood, 18, pp. 62-75. [in Ukrainian].

Kaczyński, A. (2016). Historia pobojowiska Legionów Polskich pod Kostiuchnówką w okresie II RP. Niepodległość i Pamięć, 2(54), ss. 135-151. [in Polish].

Kasianov, H. (2016). Historical Memory and Historical Policy: to the Problem of Terminology and Genealogy of Concepts. Ukrainian Historical Journal, 2, pp.118-137. [in Ukrainian].

Kronika polityczna. (1920). Robotnik: centralny organ P.P.S., 23 listopada, s. 4. [in Polish].

Krutikov, A. (2019). Fenomen Yuzefa Pilsudskogo i stoletiie polskoi nezavisimosti [Josef Pilsudki's phenomenon and the $100^{\text {th }}$ anniversary of Poland's Independence]. URL: http://www.perspektivy.info/history/fenomen_juzefa_pilsudskogo_i_stoletije_p olskoj_nezavisimosti_2019-01-30.htm. [in Russian]. (Accessed 19 February 2020).

Liebe, G. (2009). Istoriia mista L'vova v yogo politychnykh pam 'iatkakh [Lviv's History in Its Political Monuments], Seriia onlain publikatsii Tsentru miskoii istorii Tsentralno-Skhidnoii Yevropu, 6. URL: https://www.academia.edu/530732/Історія_міста_Львова_в_його_політични х_пам_ятниках. [in Ukrainian]. (Accessed 19 February 2020).

Lypovetskiy, S. (2019). Nevidomyi soldat iz lvivskogo Lychakova [Unknown Soldier from Lviv Lychakov]. URL: https://tyzhden.ua/publication/237646. [in Ukrainian]. (Accessed 19 February 2020).

Lys, S. (2012). Pro bratske pokhovannia ta pam'yatnyk polehlym v period padiansko-polskoii viiny 1920 roku u misti Lutsku [About Mass Grave and Monument to the killed in Soviet - Polish War of 1920 in Lutsk. URL: http://volyn-

museum.com.ua/publ/volinskij_kraeznavchij_muzej/pro_bratske_pokhovannja ta_pam_jatnik_poleglim_v_period_radjansko_polskoji_vijni_1920_roku_u_m isti_lucku/2-1-0-121. [in Ukrainian]. (Accessed 19 February 2020).

Medyński, A. (1937). Lwów: ilustrowany przewodnik dla zwiedzających miasto. Lwów: Inlroligatornia Aleksandra Nynki. 232 s. [in Polish].

Megill, A. (2007). Istoricheskaia epistemologiia [Historical epistemology], Moscow: «Kanon+», 480 p. [in Russian]. 
INTERMARUM: history, policy, culture. - Issue 8 .

Mick, C. (2016). Lemberg, Lwów, L'viv, 1914-1947: Violence and Ethnicity in a Contested City. West Lafayette: Purdue University Press. 445 p. [in English].

Mick, C. (2016). The dead and the living: war veterans and memorial culture in interwar Polish Galicia, Sacrifice and rebirth: the legacy of the last Habsburg War. New York, Oxford: Berghahn, pp. 233-257. [in English].

Nahirnyi, V. (2010). Idoly na zadvirkakh pam'yati [Idols in the Backround of the Memory]. Nezalezhnyi kulturologichnyi chasopys «Ï», 62, pp. 199-201. [in Ukrainian].

Obchód imenin Naczelnika Państwa (1922). Polska Zbrojna: pismo codzienne, 22 marca, s. 4. [in Polish].

Po imieninach marsz. Piłsudskiego. (1920). Robotnik: centralny organ P.P.S., 20 marca, s. 2. [in Polish].

Sakivskii, I. (2017). Diialnist' OUN u Ternopilskomu voievodstvi u 1929-1939 rr. [OUN activities in Ternopil Voivodeship in 1929-1939]. Dysertatsiia na zdobuttia naukovogo stupenia kandydata istorychnykh nauk, Kyiv, 232 p. [in Ukrainian].

Tarnopol na starych zdjęciach. Kresy Wschodnie przed II wojną światową. URL: https://www.kawiarniany.pl/2018/06/11/tarnopol-na-starychzdjeciach-kresy-wschodnie-przed-ii-wojna-swiatowa/. [in Polish]. (Accessed 19 February 2020).

The wheel of history. Monument to Polish defenders of Lutsk. http://www.hroniky.com/news/view/5317-koleso-istorii-pam-iatnyk-polskymoborontsiam-lutska. [in Ukrainian]. (Accessed 19 February 2020).

Vynnyk, O. (2018). Postwar "Normalization": The Reintegration of Disabled Veterans to Civilian Life in Interwar Lviv. A thesis submitted in partial fulfillment of the requirements for the degree of Doctor of Philosophy in History. Alberta: Department of History and Classics University of Alberta. 348 p. [in English].

W drugę rocznicę oswobodzenia Lwowa. (1920). Gazeta Lwowska, 16 listopada, s. 3. [in Polish].

W drugę rocznicę oswobodzenia Lwowa. (1920). Gazeta Lwowska, 20 listopada, s. 3. [in Polish].

W dzień chwały. (1920). Wiek Nowy: popularny dziennik ilustrowany, 23 listopada, ss. 1-3. [in Polish].

Waingertner, P. (2017). Wołyński klucz do niepodległości. Bitwa pod Kostiuchnówką 4-6 lipca 1916 roku i pamięć o niej, Dzieje Najnowsze, Rocznik XLIX, 2, ss. 39-51. [in Polish].

Wzdłuż ostatniej drogi Nieznanego Żołnierza. (1925). Gazeta Poranna: ilustrowany dziennik informacyjny wschodnich kresów, 3 listopada, s. 2. [in Polish]. 
IНТЕРМАРУМ: історія, політика, культура. - Вип. 8. ISSN 2518-7694 (Print)

ISSN 2518-7708 (Online)

Załęczny, J. (2016). Kult Piłsudskiego przed i po maju. Niepodległość i Pamięć, 23/3, (55), ss. 55-91. [in Polish].

Załęczny, J. (2017). Tradycje patriotyczne elementem kształtowania zbiorowej świadomości historycznej w II Rzeczypospolitej. Warszawa: Fundacja im. Władysława Orkana. 444 s. [in Polish].

Załęczny, J. (2019). Pamięć o uczestnikach wojny 1920 roku w świadomości społeczeństwa II RP, Niepodległość i Pamięć, 3/67, (55), ss. 185209. [in Polish].

\section{Матвійчук Віталій. ВІДНОВЛЕННЯ ДЕРЖАВНОСТІ В ІСТОРИЧНІЙ ПОЛІТИЦІ ДРУГОЇ РЕЧІ ПОСПОЛИТОЇ (НА ПРИКЛАДІ ЗАХІДНОУКРАЇНСЬКИХ ЗЕМЕЛЬ)}

\section{Анотація}

Метою статті є дослідження історичної політики Другої Речі Посполитої у 1920-x-1930-х роках. на західноукраїнських землях, пов'язаних з відновленням польської державності. Методологія наукового дослідження трунтується на основі загальнонаукових $i$ спеціальних історичних методів з урахуванням базових принцииів історичного пізнання. Принципи історизму та науковості дозволили відтворити історичну політику Другої Речі Посполитої на західноукраӥнських землях в усій ї̈ складності та багатоманітності, у взаємозв'язку $i$ взаємозумовленості з тогочасними подіями. Принцип об'єктивності допоміг підійти до розгляду окресленої проблематики $з$ урахуванням об'єктивних історичних закономірностей, $з$ критичним аналізом літературно-джерельної бази. Принщип системності дозволив сформувати иілісну картину відповідних комеморативних практик. Наукова новизна роботи полягає в тому, щчо тут уперше на основі широкої джерельної бази досліджено проблему відображення історичного сюжету відновлення Польщі у владній політищі пам'яті на західноукраїнських землях. У результаті автор приходить до висновку, що «пам'ять» про відновлення держави активно впроваджувались на всій iï території, в тому числі і на західноукраїнських землях. Через відповідну історичну політику польська влада намагалась інтегрувати західноукраӥнські землі в єдиний соиіокультурний простір, створення якого було доволі важким питанням для повоєнної Польщі. Історичні сюжети та різного роду комемораџії ставали уніфікованими для всієї території держави. Частина ж локальних сюжетів, наприклад, «львівські орлята» чи бої легіонерів під Костюхнівкою стали загальнодержавними, щцо посилило позицію польського державного 


\section{INTERMARUM: history, policy, culture. - Issue 8. ISSN 2518-7694 (Print) ISSN 2518-7708 (Online)}

наративу в західноукраїнському регіоні. Доведено активність меморіалізації західноукраїнських міст, щзо призводило до заповнення простору пам'яті польськими символами. Також розглядається питання формалізму та одноманітності польських комеморативних практик в Західній Украӥні

Ключові слова: комеморативні практики, історична політика, західноукраӥнські землі, міжвоєнний період, Друга Річ Посполита.

\section{Matwijczuk Witali. PRZYWRÓCENIE PAŃSTWOWOŚCI W HISTORYCZNEJ POLITYCE II RZECZYPOSPOLITEJ (NA PRZYKLADZIE ZIEM ZACHODNIOUKRAIŃSKICH)}

\section{Streszczenie}

Celem artykułu jest zbadanie polityki historycznej II Rzeczypospolitej w latach 20. i 30. XX wieku na zachodnich ziemiach ukrainskich zwiazanych $z$ przywróceniem państwowości polskiej. Metodologia badań naukowych oparta jest na ogólnych naukowych $i$ specjalnych metodach historycznych, biorac do uwagi podstawowe zasady poznania historycznego. Zasady historyzmu $i$ naukowości pozwolity na odtworzenie polityki historycznej II Rzeczypospolitej $n a$ ziemiach zachodnioukraińskich $w$ całej jej złożoności i różnorodności, $w$ zwiazku $i$ wspótzależności $z$ wydarzeniami tamtych czasów. Zasada obiektywizmu pomogła podejść do analizy określonego problemu, biorac do uwagi obiektywe regularności historyczne, z krytyczna analiza literatury i bazy źródłowej. Zasada systematyczności pozwoliła stworzyć całościowy obraz odpowiednich praktyk upamiętnienia. Oryginalnościa naukowa pracy jest to, że po raz pierwszy na podstawie szerokiej bazy źródłowej podjęto problem wyświetlania historycznej fabuly odbudowy Polski w rzadowej polityce pamięci na zachodnich ziemiach ukraińskich. W wyniku autor stwierdza, że „pamięć”o odbudowie państwa byta aktywnie wprowadzana na catym jego terytorium, włacznie na zachodniej Ukrainie. Ze względu na odpowiedniq polityke historyczna polski rzad starat się zintegrować zachodnie ziemie ukrainskie $w$ jedna przestrzeń społeczno-kulturowa, której stworzenie było dla powojennej Polski zagadnieniem dość trudnym.

Na calym terytorium państwa zunifikowano watki historyczne i różnego rodzaju upamiętnienia. Niektóre $z$ tutejszych wątków, jak np. „Orlęta Lwowskie" czy bitwy legionistów pod Kostiuchnówka, staty się ogólnokrajowe, co umocnito pozycję polskiej narracji państwowej w zachodniej Ukrainie. Udowodniono działanie upamiętniajace miasta zachodniej Ukrainy, które doprowadzity do wypetnienia przestrzeni pamięci polskimi symbolami. 
IНТЕРМАРУМ: історія, політика, культура. - Вип. 8. ISSN 2518-7694 (Print) ISSN 2518-7708 (Online)

Poruszono również kwestię formalizmu i jednolitości polskich praktyk upamiętnienia na zachodniej Ukrainie.

Stowa kluczowe: praktyki upamiętnienia, polityka historyczna, ziemie zachodniej Ukrainy, okres międzywojenny, II Rzeczpospolita.

The article was received 06.05 .2020

Article recommended for publishing 09.12.2020 